\title{
Open traumatic brain injury by nail gun resulting in a persistent vegetative state
}

Figure 1 Preoperative radiographic imaging
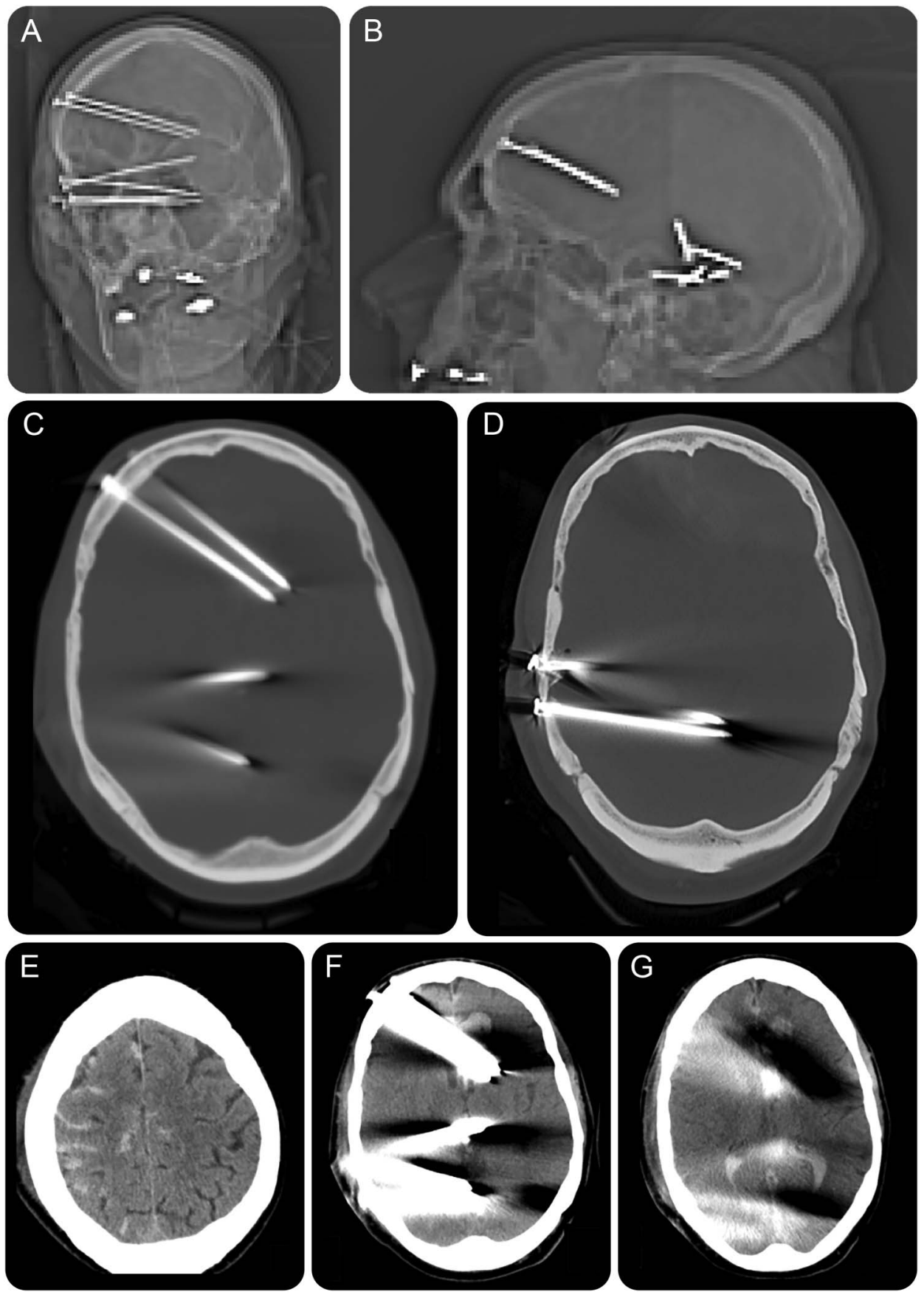

(A, B) Scout $x$-ray and (C-G) head CT without contrast. Metallic foreign bodies traverse the right frontal and temporal calvaria into the superior cerebellum, right frontal and temporal lobes, and bilateral thalami. Subarachnoid, intraventricular, and intraparenchymal hemorrhages are notable despite artifacts. 

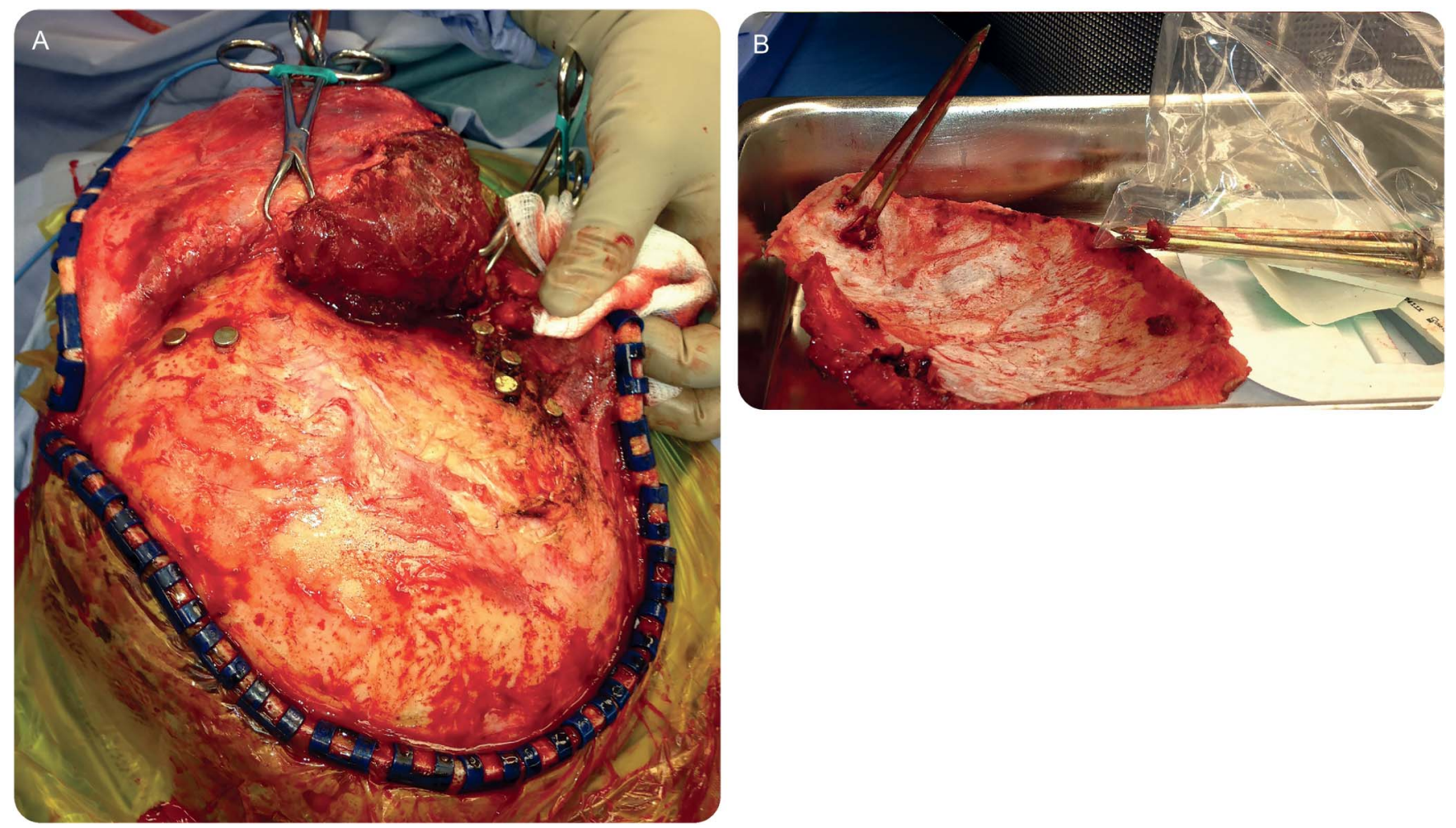

Intraoperative photographs of nails within (A) the right hemicalvarium and (B) the craniectomy flap.

A 64-year-old man presented to the trauma bay with metallic objects protruding from his right scalp following presumed assault. Clinical examination demonstrated an unresponsive, moderately hypertensive patient with reactive pupils, intact corneal and gag reflexes, and no movement to noxious stimuli (Glasgow Coma Scale ${ }^{1}$ 3T). Neuroimaging demonstrated multiple linear metallic foreign bodies extending deep into the bilateral thalami and brain parenchyma (figure 1). The patient underwent a right decompressive hemicraniectomy and removal of seven 10-inch nails through the skull via the right frontal and temporal cortices (figure 2). The patient recovered and remains in a persistent vegetative state, likely from his diencephalic injury. ${ }^{2}$

Jayesh P. Thawani, MD, Timothy H. Lucas, MD, PhD

From the Department of Neurosurgery, Hospital of the University of Pennsylvania, Philadelphia.

Author contributions: Jayesh P. Thawani drafted the manuscript and edited the figures. Timothy H. Lucas drafted/edited the manuscript and was the treating physician.

Study funding: No targeted funding reported.

Disclosure: The authors report no disclosures relevant to the manuscript. Go to Neurology.org for full disclosures.

Correspondence to Dr. Thawani: jayesh.thawani@uphs.upenn.edu

1. Teasdale G, Jennett B. Assessment of coma and impaired consciousness: a practical scale. Lancet 1974;2:81-84.

2. Kinney HC, Korein J, Panigrahy A, Dikkes P, Goode R. Neuropathological findings in the brain of Karen Ann Quinlan: the role of the thalamus in the persistent vegetative state. N Engl J Med 1994;330:1469-1475. 


\section{Neurology}

\section{Open traumatic brain injury by nail gun resulting in a persistent vegetative state}

Jayesh P. Thawani and Timothy H. Lucas

Neurology 2016;86;1358-1359

DOI 10.1212/WNL.0000000000002549

\section{This information is current as of April 4, 2016}

\section{Updated Information \& Services}

References

Subspecialty Collections

Permissions \& Licensing

Reprints including high resolution figures, can be found at: http://n.neurology.org/content/86/14/1358.full

This article cites 2 articles, 0 of which you can access for free at: http://n.neurology.org/content/86/14/1358.full\#ref-list-1

This article, along with others on similar topics, appears in the following collection(s):

All Education

http://n.neurology.org/cgi/collection/all_education

Brain trauma

http://n.neurology.org/cgi/collection/brain_trauma

Information about reproducing this article in parts (figures,tables) or in its entirety can be found online at:

http://www.neurology.org/about/about_the_journal\#permissions

Information about ordering reprints can be found online:

http://n.neurology.org/subscribers/advertise

Neurology ${ }^{\circledR}$ is the official journal of the American Academy of Neurology. Published continuously since 1951, it is now a weekly with 48 issues per year. Copyright @ 2016 American Academy of Neurology. All rights reserved. Print ISSN: 0028-3878. Online ISSN: 1526-632X.

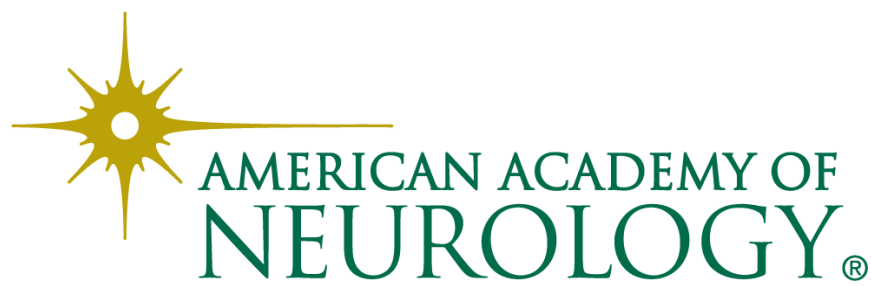

